\title{
Cost estimate of hospital stays for premature newborns of adolescent mothers in a Brazilian public hospital
}

\author{
Estimativa de custo de permanência hospitalar para recém-nascidos prematuros \\ de mães adolescentes em um hospital público brasileiro
}

\author{
Lutufyo Witson Mwamakamba ${ }^{1}$, Paola Zucchi ${ }^{1}$
}

\begin{abstract}
Objective: To estimate the direct costs of hospital stay for premature newborns of adolescent mothers, in a public hospital. Methods: A cost estimate study conducted between 2009 and 2011, in which direct hospital costs were estimated for premature newborns of adolescent mothers, with 22 to 36 6/7 gestational weeks, and treated at the neonatal unit of the hospital. Results: In 2006, there were 5,180 deliveries at this hospital, and $17.8 \%$ (922) were newborns of adolescent mothers, of which $19.63 \%$ (181) were admitted to the neonatal unit. Out of the 181 neonates, 58\% (105) were premature and $80 \%(84)$ of them were included in this study. These 84 neonates had a total of 1,633 days in-patient hospital care at a total cost of US\$195,609.00. Approximately $72 \%$ of this total cost (US $\$ 141,323.00$ ) accounted for hospital services. The mean daily costs ranged from US $\$ 97.00$ to US $\$ 157.00$. Conclusion: This study demonstrated that the average cost of premature newborns from adolescent mothers was US $\$ 2,328.00$ and varied according to birth weight. For those weighing $<1,000 \mathrm{~g}$ at birth, the mean direct cost was US\$8,930.00 per stay as opposed to a cost of US\$642.00 for those with birth weight $>2,000 \mathrm{~g}$. The overall estimated direct cost for the 84 neonates in the study totaled US\$195,609.00.
\end{abstract}

Keywords: Cost and cost analysis; Pregnancy in adolescence; Obstetric labor, premature; Infant, premature; Intensive care, neonatal

\section{RESUMO}

Objetivo: Estimar os custos diretos de internações de recém-nascidos prematuros de mães adolescentes em um hospital público. Métodos: Estudo de estimativa de custos realizado entre 2009 e 2011, no qual os custos hospitalares diretos foram estimados para recém-nascidos prematuros de mães adolescentes, com 22 a 36 6/7 semanas de gestação, e tratados na unidade neonatal do hospital. Resultados: Em 2006, o hospital em estudo teve 5.180 partos; 17,8\% (922) foram de mães adolescentes, e 19,63\% (181) recém-nascidos foram admitidos na unidade neonatal. Dos 181 neonatos, 58\% (105) eram prematuros, dos quais $80 \%$ (84) foram incluídos neste estudo. Estes 84 recémnascidos totalizaram 1.633 dias de tratamento hospitalar, a um custo total de US\$195,609.00. Aproximadamente $72 \%$ desse custo total (US\$141,323.00) referiu-se a serviços hospitalares. Os custos médios diários variaram de US\$97.00 a US\$157.00. Conclusão: Este estudo demonstrou que o custo médio de recém-nascido prematuro de mães adolescentes foi US $\$ 2,328.00$ e variou de acordo com o peso ao nascimento. Para recém-nascidos com peso $<1.000 \mathrm{~g}$ ao nascer, 0 custo médio foi US\$8,930.00, e para os que pesaram $>2.000 \mathrm{~g}$ foi de US $\$ 642.00$. 0 custo hospitalar total estimado para os 84 neonatos no estudo foi de US\$195,609.00.

Descritores: Custo e análise de custo; Gravidez na adolescência; Trabalho de parto prematuro; Prematuro; Terapia intensiva neonatal

\section{INTRODUCTION}

Since the 1980's, the number of newborn intensive care units (ICU) has increased dramatically. This increase was associated with significant costs and a considerable amount of heterogeneity between countries, or even within a country, when it comes to allocation of resources and distribution of critical care services. ${ }^{(1)}$

It is evident that there is a paucity of studies that specifically address intensive care costs, ${ }^{(2)}$ with variations in study populations and differing economic evaluation methods. $^{(3)}$ Thus, there is constant need for cost

\footnotetext{
${ }^{1}$ Universidade Federal de São Paulo, São Paulo, SP, Brazil.

Corresponding author: Lutufyo Witson Mwamakamba - Rua Botucatu, 680 - Vila Clementino - Zip code: 04023-062 - São Paulo, SP, Brazil - Phone: (55 11) 5575-6427 - E-mail: lutufyomd@yahoo.com Received on: Aug 23, 2013 - Accepted on: Dec 27, 2013

Conflicts of interest: none.

DOI: 10.1590/S1679-45082014GS2959
} 
evaluation and economic analyses especially about direct medical costs, which impact on the finances of the hospital.

Adolescent pregnancy, in which the mother is aged between 10 and 19 years, has become a multifaceted matter involving social, cultural, educational, health and economic issues of vast diversity. Consequently, the high cost of caring for neonates has raised much concern about preterm labor in adolescent mothers. ${ }^{(4)}$

The prevalence of preterm births varies from region to region. According to the World Health Organization, as of 2006 in the United States about 12 to $13 \%$ of all births were preterm. ${ }^{(5,6)}$ These premature newborns (PN) accounted for expensive hospital treatments and numerous days of hospital care when compared to term infants. ${ }^{(6,7)}$

\section{The Brazilian perspective}

In Brazil, in 2006, $20 \%$ of the 186,770,613 inhabitants $(38,822,165)$ were adolescents aged 10 to 19 years. Of these, $49 \%(19,251,110)$ were female according to the Brazilian Institute of Geography and Statistics (IBGE). ${ }^{(8)}$ Of the 2,944,928 neonates born in Brazil in 2006, $21 \%$ were born to adolescent mothers $(27,610$ mothers aged 10 to 14 years and 605,270 aged 15 to 19 years). Astonishingly, of the total number of $161,271 \mathrm{PN}, 27.84 \%(44,906)$ were born to adolescent mothers, who had a preterm rate of $7 \%$, compared to $5 \%$ among non-adolescents. ${ }^{(9)}$ However, it is important to note the variation of obstetrical characteristics of these pregnancies from one region to another, due to heterogeneous socioeconomic factors. ${ }^{(10,11)}$ In terms of neonatal beds, in the same year of 2006, there was 1.6 neonatal bed per 1,000 inhabitants with the majority of these beds located in the city of São Paulo, both within the private and public sectors. ${ }^{(12)}$

\section{OBJECTIVE}

To estimate direct hospital costs of premature newborns of adolescent mothers, in a public hospital.

\section{METHODS}

\section{Study design and setting}

A cost estimation study, conducted at Centro Paulista de Economia da Saúde, at the Universidade Federal de São Paulo (UNIFESP), at São Paulo (SP), Brazil, from 2009 to 2011. Data were collected from Hospital Municipal e Maternidade-Escola Vila Nova Cachoeirinha Dr. Mario de Moraes Altenfelder Silva (HMMEVNC), a tertiary public hospital in the city of São Paulo, located in one of the 96 districts, in the Northern region.

This hospital is classified as a healthcare facility level 8 by the Brazilian National Register of Healthcare Facilities (CNES, abbreviation in Portuguese) and provides high complex procedures to inpatients and outpatients. ${ }^{(13)}$ The organization provides continuous service, 24 hours a day, 7 days per week, and it is a reference center for high-risk pregnant women and newborns of 18 districts.

The hospital had 170 planned beds and 155 operational beds, of which 52 were neonatal beds; in that, 20 were in ICU, 20 in the stepdown unit (SD) and 12 in intermediate care (IC). There were approximately 500 births per month.

The hospital team comprised the following fulltime healthcare professionals: 84 nurse technicians, 32 neonatologists, 12 registered nurses, 7 physical therapists, and 2 speech therapists, as well as on-call professionals including, radiologists, cardiologists, neurosurgeons etc. The overall mean occupancy rate of the neonatal unit, calculated through daily census in 2006 , was $75 \%$, with an occupancy rate in each unit of $88 \%$ in ICU, $63 \%$ in SD and $80 \%$ in IC, and a mortality rate of $7 \%$.

\section{Study population}

The study included all adolescents aged 10 to 19 years, with singleton pregnancies delivered at the hospital, from January to December of the same year (2006), with preterm gestations of 22 to $366 \backslash 7$ weeks. Gestations of less than 22 weeks were not considered due to their unviability. ${ }^{(14)}$

It is evident that an accurate estimation of gestational age is paramount in obstetric care decisions that directly influence the PN. Obtaining an accurate and reliable gestational age in adolescents is influenced by numerous factors: the uncertainty regarding the last menses period and late onset of prenatal care, which alter the gestational age based on the ultrasound calculation.

In this study, the gestational age was determined based on clinical examination using the New Ballard score: a physical and neurological examination, performed in the first 12 hours of life by neonatologists. This test was considered due to the fact that there is a predictable pattern of changes occurring throughout gestation, and this is an accurate test when compared to other tests. ${ }^{(15)}$

The inclusion criteria were PN $\geq 24$ hours of life, born at the HMMEVNC, admitted to the neonatal unit. The neonates were classified into four subgroups due to the level of risk and mortality that is directly related to weight $(<1,000 \mathrm{~g}, 1,000$ to $1,499 \mathrm{~g}, 1,500$ to $1,999 \mathrm{~g}$ and $>2,000 \mathrm{~g})$. 
The exclusion criteria were $\mathrm{PN}$ with severe congenital malformations or those that were transferred to other facilities for further treatments, as these factors made it difficult in obtaining reliable medical costs, as well as the impact on cost minimization or maximization depending on the severity. ${ }^{(16)}$ The PN born to mothers with a prior history of other medical conditions were also excluded in order to minimize the intrinsic adverse effects of these pathologies on pregnancy.

\section{Sources of data}

The medical records were collected from the Medical Files Storage and Statistical Service of the hospital. Data on gestation, mothers and neonates were retrieved from the medical records and the newborn ICU.

Direct hospital costs, as used in this study, refer to "cost for goods and services used in diagnosis, prevention, treatment and rehabilitation of a patient". (17) Data relating to direct medical costs estimate were obtained from the hospital pharmacy, human resources, finance, central storage and purchasing departments and the neonatal unit. The costs were calculated from the day of birth to the day of discharge. The direct medical costs focused exclusively on care rendered in the NICU.

The direct cost of hospital care included the hospital services described below.

\section{Hospital services}

High cost medications, such as surfactant, prostaglandins and others, have proven to have a significant impact on cost. ${ }^{(18)}$ The cost estimate for these drugs was based on the unit price of purchase at the time of utilization and multiplied according to individual usage. The cost of low cost medications, such as antibiotics, analgesic drugs and others, was based on the purchase price after summing up each medication in use by the neonatal unit, in 2006, divided by 365 days, and multiplied individually according to the utilization based on diagnosis and days of use. This method was also utilized for nursing care materials, such as syringes, cotton, assepsis products, and other, regardless of diagnosis.

The estimate of parenteral nutrition cost was based on daily purchase price and multiplied according to days of utilization.

Concerning medical gases, the gas and dispensing equipment were considered. For gases such as oxygen, the cost estimate was done after calculating the cost per cubic meter of oxygen delivered at $1 \mathrm{~L} /$ minute. An average of oxygen utilization per $\mathrm{L} /$ minute was determined in three modalities (orotracheal ventilation/nasal ventilation and oxygen therapy without invasive procedures). The average obtained was further multiplied according to days of utilization in each modality by the patient. This value was added to the ventilating equipment when applicable, and the cost estimate was calculated by taking into account purchase and maintenance values, accumulated depreciation and utilities necessary to main the equipment. ${ }^{(19)}$ This same method was applied to estimate the cost of other pieces of equipment, such as monitors, and estimates were calculated according to days of use by each patient.

Clinical services were defined as support services that are directly related to patient care, but were not supplied by the ICU, such as radiology, nutrition, speech therapy and audiology, physical therapy etc. In this study, two procedures were considered; physical therapy and speech therapy and audiology. The cost estimate was based on the number of sessions multiplied by days of utilization, and the values were obtained from the List of Medical Procedures published by the Brazilian Medical Association (abbreviation in AMB). ${ }^{(20)}$ The other procedures were not included due to incomplete financial information that could be tracked directly to the patient.

Manpower was defined as the net pay for nursing and medical staff employed full-time in the ICU. The cost of nursing services was determined on the basis of the average salary of nurses who had been employed for an average of 2 years. The total number of nurse-hours was calculated for the sector, and the total of all tallies was divided by this total number of hours to obtain the cost per hour worked within this category. Medical services were based on the average salary of neonatologists who had worked for 2 years at the hospital. The salaries were calculated in full and calculated according to working hours.

Diagnostic tests were additional exams to help making clinical diagnoses, as blood tests, biochemical profiles, blood gas analysis, immunology tests, X-rays, ultrasounds, and eye exams. The costs of these exams were obtained from the AMB list. ${ }^{(20)}$

Costs of blood products were calculated according to the tables available from private blood banks for red blood cell concentrate, plasma, platelets and coagulation factors.

The costs related to electrical power, water, telephone services, administrative expenses, general expenses, cleaning, maintenance, laundering, diet and nutritional expenses were considered as indirect costs that comprise the hospital overhead and were not included in the study. The results of this study were compared with those of international studies by exchanging the values of this study from Brazilian currency (real) into US dollars, at an exchange rate of 2.25354 (the annual average rate in 2006). ${ }^{(21)}$ 


\section{Ethical aspects}

Ethical approval for this study was obtained from the ethical and research committees of Maternidade Municipal Escola de Vila Nova Cachoeirinha, protocol 011/2007, and of Escola Paulista de Medicina of Universidade Federal de São Paulo, protocol 1961/07.

\section{Statement of consent}

The objective of this study is to estimate direct hospital costs of premature newborns of adolescent mothers, in a public hospital in the city of São Paulo (SP), Brazil.

Data collection was conducted by the investigator using patient's medical records and other resources without any risk to the patients or to the organization of

Table 1. Distribution of hospital stay according to birth weight

\begin{tabular}{lcccc}
\hline Birth weight & $\mathbf{<} \mathbf{1 , 0 0 0} \mathbf{g}$ & $\mathbf{1 , 0 0 0 - 1 , 4 9 9 g}$ & $\mathbf{1 , 5 0 0 - 1 , 9 9 9} \mathbf{g}$ & $\mathbf{2} \mathbf{2 , 0 0 0} \mathbf{g}$ \\
\hline NB, $n$ & 4 & 13 & 32 & 35 \\
Total days of hospital care & 227 & 637 & 539 & 230 \\
Average & 56.75 & 49.0 & 16.80 & 6.57 \\
Length of stay at ICU (days) & 129 & 339 & 190 & 55 \\
Average & 32.25 & 26.0 & 5.93 & 1.57 \\
Length of stay at SD (days) & 98 & 298 & 300 & 26 \\
Average & 24.5 & 22.90 & 9.34 & 0.74 \\
Length of stay at IC (days) & - & - & 49 & 149 \\
Average & - & - & 1.53 & 4.25 \\
\hline
\end{tabular}

NB: newborn; ICU: intensive care unit; SD: step-down unit; IC: intermediate care unit. the study, with data exclusive for this study. At any stage of the project, the data will be available for any clarification. It assures freedom to withdraw consent at any time and termination of this study without any prejudice to the institution and constant updating. It also assures the right of confidentiality of patients' information, with no disclosure of their identification.

\section{RESULTS}

In 2006, the hospital had 5,180 newborns with more than 24 hours of life. Of these newborns, $17.8 \%$ (922) were from adolescents, of which $19.63 \%$ (181) were admitted to the neonatal unit. Of the 181 neonates admitted to the neonatal unit, 58\% (105) were PN and $80 \%$ (84) were included in this study. The remaining $20 \%, 8 \%$ were younger than 24 hours of life, $7 \%$ had congenital malformations and the others could not be included due to incomplete medical records. The 84 PN were classified as follows: 4 neonates $<1,000 \mathrm{~g}$; 13 neonates with 1,000 to $1,499 \mathrm{~g} ; 32$ neonates with 1,500 to $1,999 \mathrm{~g}$; 35 neonates with 2,000 to $2,499 \mathrm{~g}$.

The mean age observed in the 84 adolescent mothers was 16 years, range of 14 to 19 years, about $58.33 \%$ (49) were single mothers, $84.52 \%$ (71) had completed the 8 th grade (junior school), while $71.42 \%$ (60) were primigravid and $79.76 \%$ (67) had at least three prenatal care appointments.

Table 2. Cost of hospital services for premature newborns by birth weight

\begin{tabular}{|c|c|c|c|c|}
\hline Birth weight & $<1,000 \mathrm{~g}$ & $1,000-1,499 g$ & $1,500-1,999 \mathrm{~g}$ & $>2,000 \mathrm{~g}$ \\
\hline$N B, n$ & 4 & 13 & 32 & 35 \\
\hline \multicolumn{5}{|l|}{ Hospital services } \\
\hline Medicinal gases: total days of use $\mathrm{O}_{2}$ & 118 & 305 & 162 & 56 \\
\hline Total cost of $\mathrm{O}_{2}$ utilization & US\$3,045.00 & US\$4,755.00 & US\$1,905.00 & US\$627.00 \\
\hline Cost $\mathrm{O}_{2}$ per NB & US\$759.00 & US\$366.00 & US\$60.00 & US\$18.00 \\
\hline Parenteral nutrition utilization, number of requests & 49 & 83 & 35 & 12 \\
\hline Total cost of parenteral nutrition per NB & US\$2,500.00 & US\$4,194.00 & US\$1,775.00 & US\$612.00 \\
\hline Average cost of parenteral nutrition per NB & US\$625.00 & US\$326.00 & US\$56.00 & US\$26.00 \\
\hline Nursing supplies per NB & US\$917.00 & US\$814.00 & US\$229.00 & US\$180.00 \\
\hline Total value of nursing materials & US\$3,668.00 & US\$10,582.00 & US\$7,328.00 & US\$6,300.00 \\
\hline Average cost of low cost medications per NB & US\$887.00 & US\$819.00 & US\$190.00 & US\$40.00 \\
\hline Total costs of low cost medications & US\$3,548.00 & US\$10,647.00 & US\$6,080.00 & US\$1,398.00 \\
\hline Average cost of high cost medications per NB & US\$641.00 & US\$232.00 & US\$47.00 & US\$7.00 \\
\hline Total costs of high cost medications & US\$2,564.00 & US\$3,016.00 & US\$1,504.00 & US\$245.00 \\
\hline Special material per NB & US\$117.25 & US\$6,769.00 & US\$625.00 & US\$485.00 \\
\hline Total value of special supplies & US\$469.00 & US\$880.00 & US\$200.00 & US\$170.00 \\
\hline Professional services: Average cost of professional services per NB & US\$2,336.00 & US\$2,022.00 & US\$671.00 & US\$183.00 \\
\hline Total costs of professional services & US\$9,353.00 & US\$26,015.00 & US\$21,530.00 & US\$6,404.00 \\
\hline Total costs of hospital services & US\$25,146.00 & US\$60,089.00 & US\$40,322.00 & US\$15,756.00 \\
\hline Average cost of hospital services per NB & US\$6,286.00 & US\$4,622.00 & US\$1,260.00 & US\$450.00 \\
\hline
\end{tabular}


Table 3. Proportional composition of hospital services, diagnostic tests and blood products by weight

\begin{tabular}{|c|c|c|c|c|}
\hline Birth weight & $<1,000 \mathrm{~g}$ & $1,000-1,499 g$ & $1,500-1,999 g$ & $>2,000 \mathrm{~g}$ \\
\hline Number of newborns & 4 & 13 & 32 & 35 \\
\hline \multicolumn{5}{|l|}{ Professional services } \\
\hline Physicians & US\$2,545.00 & US\$7,135.00 & US\$5,787.00 & US\$1,946.00 \\
\hline Nursing staff & US\$6,054.00 & US\$16,054.00 & US\$13,391.00 & US\$3,614.00 \\
\hline Speech therapists and physical therapists & US\$754.00 & US\$2,826.00 & US\$2,352.00 & US\$834.00 \\
\hline Total costs of professional services & US\$9,353.00 & US\$26,015.00 & US\$21,530.00 & US\$6,404.00 \\
\hline Average cost of professional services per NB & US\$2,338.00 & US\$2,001.00 & US\$673.00 & US\$183.00 \\
\hline \multicolumn{5}{|l|}{ Diagnostic tests } \\
\hline Radiology & US\$2,451.00 & US\$4,430.00 & US\$3,507.00 & US\$1,469.00 \\
\hline Hemotological tests & US\$7,292.00 & US\$15,297.00 & US\$12,081.00 & US\$5,158.00 \\
\hline Microbiology & US\$378.00 & US\$515.00 & US\$755.00 & US\$644.00 \\
\hline Average costs per NB & US\$2,530.00 & US\$1,557.00 & US\$510.00 & US\$189.00 \\
\hline Total costs of diagnostic tests & US\$10,121.00 & US\$20,242.00 & US\$16,343.00 & US\$6,627.00 \\
\hline \multicolumn{5}{|l|}{ Blood products } \\
\hline Total costs of blood products: red blood cells, plasma, platelets concentrate & US\$455.00 & US\$411.00 & US\$142.00 & US\$97.00 \\
\hline
\end{tabular}

NB: newborn.

Table 4. Direct costs of hospital stay for preterm newborns in the neonatal intensive care unit

\begin{tabular}{|c|c|c|c|c|}
\hline Birth weight & $<1,000 \mathrm{~g}$ & $1,000-1,499 g$ & $1,500-1,999 \mathrm{~g}$ & $>2,000 \mathrm{~g}$ \\
\hline Number of newborns & 39 & 13 & 32 & 35 \\
\hline Total length of stay, days & 227 & 637 & 539 & 230 \\
\hline Average length of stay, days & 56 & 49 & 16.8 & 6.6 \\
\hline Hospital services & US $\$ 25,146.00$ & US $\$ 60,089.00$ & US\$40.322.00 & US $\$ 15,756.00$ \\
\hline Diagnostic tests & US $\$ 10,121.00$ & US\$20,242.00 & US\$16,343.00 & US\$6,627.00 \\
\hline Blood products & US\$455.00 & US\$411.00 & US\$142.00 & US\$97.00 \\
\hline Overall total costs & US\$35,722.00 & US\$80,742.00 & US\$56,665.00 & US $\$ 22,480.00$ \\
\hline Average cost per NB & US\$8,930.00 & US\$6,210.00 & US\$1,770.00 & US\$642.00 \\
\hline Daily cost in the NU & US\$157.00 & US\$126.00 & US\$105.00 & US\$97.00 \\
\hline
\end{tabular}

$\mathrm{NB}$ : newborn; NU: neonatal unit.

Among the 84 adolescents, 48 hours prior to birth: $47.62 \%$ (40) received treatments as inpatients, including tocolytics, corticosteroids, antibiotics and rest; $35.71 \%$ (30) received treatments as outpatients, which consisted of antibiotics and rest, and 14\% (17) had no specific treatments.

As to the probable cause of preterm labor, the following diagnosis at the onset of preterm labor were identified: urinary tract infection in $60.0 \%$ (50) of these adolescents; gestational hypertension in $11.90 \%$ (10); preterm labor of unknown cause in $11.90 \%$ (10); premature rupture of membranes, onset of labor within 24 hours in $11.90 \%$ (10); and abruption placentae in $4(4.28 \%)$.

\section{Costs}

Tables 1 to 4 illustrate the calculated direct hospital costs of the PN according to the subgroups and variables used in direct hospital cost estimate, including hospital services, diagnostic tests and blood products as well as length of stay accumulated by these PN.

\section{DISCUSSION}

\section{Brazilian perspective}

In 2006, Brazil had a population of 19 million female adolescents. The main reason for admission to hospital of $72 \%$ of this population was pregnancy and laborrelated conditions. The probability of delivering PN was 16 to $31 \%$ as compared to 7 to $8.65 \%$ of non-adolescent mothers. ${ }^{(8,22)}$

In this study, carried out with PN from adolescent mothers with singleton pregnancies, we evidenced that the average direct cost of hospital stays for 84 PN was US $\$ 2,328.68$ and the total cost was US\$195,609.00.

Although admissions for PN weighing $<1,000 \mathrm{~g}$ accounted for only $4.76 \%$ of all preterm admissions, this group incurred approximately $18.26 \%$ of the total 
PN direct hospital costs. In addition, PN of $1,000 \mathrm{~g}$ to $1,999 \mathrm{~g}$ accounted for $58 \%$ of all preterm admissions, and they accounted for approximately $70 \%$ of the total direct costs. Finally, PN >2,000g represented $41.66 \%$ of the $84 \mathrm{PN}$ admitted to the neonatal unit, incurring about $10 \%$ of hospital costs.

The median length of stay for all $84 \mathrm{PN}$ was 19.44 days; hospital services accounted for $72.22 \%$ of all costs, of which $44.80 \%$ dedicated to salaries, and $27.26 \%$ spent on therapeutic and diagnostic services. PN weighing $\leq 1,000 \mathrm{~g}$ accounted for average costs per newborn of US\$8,930.00, and neonates weighing $>2,000 \mathrm{~g}$, incurred the lowest cost (US\$642.00).

These results are consistent with numerous other studies, regardless heterogeneous sources, designs and methods, that is, 45 to $75 \%$ of direct neonatal costs were due to salaries, and an overall significant hospital cost varied according to birth weight. ${ }^{(23)}$

Comparing this study to other investigations conducted in Brazil, we noted that there are scarce studies on direct hospital costs, specifically on PN of adolescent mothers. Study conducted in a public hospital in the city of Sao Paulo, in 2004, estimated the direct hospital costs of PN of all pregnant women. Authors indicated cost variation, as neonates weighing $<1,000 \mathrm{~g}$ and from 1,000 to $1,499 \mathrm{~g}$ had mean hospital stay of 34 and 42 days, with average neonatal costs of US $\$ 3,919.00$ and US $\$ 4,043.00$, respectively. For those weighing from 1,500 to $1,999 \mathrm{~g}$ and $>2,000 \mathrm{~g}$, the average cost ranged from US $\$ 1,768.00$ to US\$1,183.00, and the total direct cost of treatment for PN was US\$2,017.00. (24)

This study showed that PN weighing $<1,000 \mathrm{~g}$ and from 1,000 to $1,499 \mathrm{~g}$ had a mean hospital stay of 56 and 49 days, with average neonatal costs of US\$8,930.00 and US $\$ 6,210.00$, respectively. The difference in costs may be attributed to comorbidities that are associated with $\mathrm{PN}$ in adolescents that are directly proportional to costs, such as prenatal care. ${ }^{(25,26)}$ Thus there is potential risk of developing several conditions that is inversely proportional to vulnerability of gestational age. (27)

Based on the Ministry of Health estimates of costs per diagnosis, in 2006, the average cost of PN was US $\$ 979.00$ versus US\$223.65, in general pediatric care. ${ }^{(28)}$ These values further demonstrate the underestimated data from the government in terms of costs.

\section{Limitations of the study}

It was necessary to round up calculations due to lack of an accounting system that evaluates costs of hospital stay. Such system is not always available, especially in public organizations in Brazil. ${ }^{(18)}$ Besides, ancillary costs were not included in this study, and they may sum up to $15.7 \%$ of overall overhead costs. ${ }^{(29)}$

Despite the fact that this study was conducted in 2011, with data available from 2006, it can be observed that the Brazilian accumulated annual inflation rate (IPCA, Índice Nacional de Preços ao Consumidor Amplo, in Portuguese), from 2006 to 2012, amounts to $36.03 \%$ of costs. ${ }^{(9)}$ The total direct cost of US\$195,609.00, in 2006, would be US\$266,028.00, in 2012. . $^{(30)}$

Finally, the reference of payments by the Brazilian public health system and the fees established by the AMB to officially calculate costs are extremely outdated, leading to a potential risk of cost underestimate..$^{(13,20)}$

\section{CONCLUSION}

Despite the general notion that premature newborn leads to high medical cost, in Brazil there are scarce studies estimating the direct medical neonatal costs for these babies, specifically those of adolescent mothers. This study was conducted a public hospital and demonstrated that the average cost of premature newborn of adolescent mother was US $\$ 2,328.00$. The costs varied according to birth weight and decreased exponentially with advanced gestational age, whereas premature newborn weighing $<1,000 \mathrm{~g}$ had an average direct cost of US\$8.930,00 versus US\$642.00 for those weighing $>2,000 \mathrm{~g}$. The overall estimated direct cost with 84 neonates totalled up US\$195,609.00

\section{REFERENCES}

1. Angus DC, Shorr AF, White A, Dremsizov TT, Schimtz RJ, Kelley MA; Committee on Manpower for Pulmonary and Critical Care Societies (COMPACCS). Critical care delivery in the United States: distribution of services and compliance with Leapfrog recommendations. Crit Care Med. 2006;34(4):1016-24.

2. Heyland DK, Kernerman P, Gafni A, Cook DJ. Economic evaluations in the critical care literature: do they help us improve the efficiency of our unit? Crit Care Med. 1996;24(9):1591-8.

3. Scott RD II, Roberts RR. The attributable cost of resistant infections in hospitals settings: economic theory and applications. In: Owens RC, LautenbachE, editors. Antimicrobial resistance: problem pathogens and clinical countermeasures. New York: Informa Healthcare; 2008. p. 1-24.

4. Eure CR, Lindsay MK, Graves WL. Risk of adverse pregnancy outcomes in young adolescent parturients in an inner-city hospital. Am J Obstet and Gynecol. 2002;186(5):918-20

5. Beck S, Wojdyla D, Say L. Betran AP, Merialdi M, Requeio JH, et al. The worldwide incidence of preterm birth: a systematic review of maternal mortality and morbidity. Bull World Health Organ. 2010;88(1):31-8. Review.

6. Petrou S. Economic consequences of preterm birth and low birthweight. BJOG. 2003;110 Suppl 20:17- 23. Review.

7. Russell RB, Green NS, Steiner CA, Meikle S, Howse JL, Poschman K, et al. Cost of hospitalization for preterm and low birth weight infants in the United States. Pediatrics. 2007;120(1):e1-9.

8. Instituto Brasileiro de Geografia e Estatística (IBGE). Pesquisa nacional por amostra de domicílios - por grupos de idade, 2005 a 2006. [Internet] 
[cited 2013 Dec 26]. http://www.ibge.gov.br/home/estatistica/populacao/ trabalhoerendimento/pnad2006/sintese/tab1_3.pdf

9. Brasil. Ministério da Saúde. Departamento de informática do Sistema Único do Saúde (DATASUS). Sistema de informações sobre nascidos vivos (SINASC) [Internet]. Brasília (DF): [citado 2005 Dez 26]. Disponível em: www.datasus.gov.br

10. Suzuki CM, Ceccon ME, Falcão MC, Vaz FA. Comparative analysis of prematurity and low birth weight between newborns of adolescent and adult mothers. Rev Bras Crescimento Desenvolv Hum. 2007;17(3):95-103.

11. Loto OM, Ezechi OC, Kalu BK, Loto L, Ezechi L, Ogunniyi SO. Poor obstetric performance of teenagers: is it age or quality of care related? J Obstet Gynaecol. 2004;24(4):395-8.

12. Brasil, Ministério da Saúde - PROADESS. Avaliação do Desempenho do Sistema de Saúde Brasileiro: indicadores de monitoramento 2012. [Internet]. Brasília (DF): [cited 2013 Dez 29] Available at: http://www.proadess.icict. fiocruz.br/Relatorio_Proadess_08-10-2012.pdf

13. Brasil. Ministério da Saúde. Secretaria da Atenção da Saúde (CNESNet). Brasília (DF); [citado em 2013 Dez 26]. Disponível em http://cnes.datasus.gov.br/

14. Chiswick. M. Infants of borderline viability: ethical and clinical considerations. Semin Fetal Neonatal Med. 2008;13(1):8-15. Review.

15. Sasidharan K, Dutta S, Narang A. Validity of New Ballard Score until $7^{\text {th }}$ day of postnatal life in moderately preterm neonates. Arch Dis Child Fetal Neonatal Ed. 2009;94(1):F39-44.

16. Wong DT, Gomez M, McGuire GP, Kavanagh B. Utilization of Intensive care unit days in a Canadian medical-surgical intensive unit. Crit Care Med. 1999;27(7):1319-24.

17. US National Library of Medicine (NIH). Health economics information resources: Direct Hospital Costs [Internet] [cited 2012 Dez 10] Available from:www.nlm.nih.gov/nichsr/edu/healthecon/glossary.html

18. Zupancic JA, Richardson DK. Characterization of neonatal personnel time inputs and prediction from clinical variables-a time and motion study. J Perinatol. 2002;22(8):658-63.

19. Narang A, Kiran PS, Kumar P. Cost of neonatal intensive care in a tertiary care center. Indian Pediatr. 2005;42(10):989-97.
20. Associação Medica Brasileira. Lista de Procedimentos Médicos 1999. [Internet] Brasilia (DF): [cited 2012 Out 05] Available http://www.connectmed.com.br/ amb/novo/inst_tabela.php3

21. Internal Revenue Agency of the USA (IRS). Yearly Average Exchange Rates for Converting Foreign Currencies into U.S. Dollars - Brazil 2012. [Internet]. [cited 2013 Dec 26]. Available from http://www.irs.gov/businesses/small/ international/article/0, id = 206089,00.html

22. Dornellas PR. Adolescentes no Brasil: Internações no Sistema Único de Saúde [dissertação]. Londrina: Universidade Estadual de Londrina; 2011.

23. Behrman RE, Bulter AS. A Systemic Review of Costs Associated with Preterm Birth. Institute of Medicine (US) Committee on Understanding Premature Birth and Assuring Healthy Outcomes. Preterm Birth: Causes, Consequences and Prevention. Washington, DC: National Press (US); 2007.

24. Desgualdo CM, Riera R, Zucchi P. Estimativa de custo de internação hospitalar para recém nascidos prematuros em um hospital publico terciário no Brasil. Clinics. 2011;66(10):1773-7.

25. Bezerra LC, Oliveira SM, Latorre MR. Prevalence and risk factors associated to preterm delivery among pregnant women submitted to preterm labor inhibition treatment. Rev Bras Matern Infantil (Recife). 2006;6 Suppl 2:223-9.

26. Zaganelli FL, Ferreira RA, Lamounier JA, Colosimo EA, Santos ASM, Zaganelli FL, et al. Gravidez da adolescente em hospital universitário no Espirito Santo, Brasil: aspectos da gestação, parto e repercussão sobre o recém-nascido. Adolesc Saude. 2013;10(1):7-16.

27. Simhan HN, Caritis SN. Prevention of preterm delivery. N Engl J Med. 2007;357(5):477-87. Review.

28. Brasil. Ministério da Saúde. Departamento de informática do Sistema Único do Saúde (DATASUS). Custo da prematuridade [Internet]. Brasília (DF); [citado 2013 Dez 26]. Disponível em: www.datasus.gov.br

29. Araujo DV, Tavares LR, Veríssimo R, Ferraz MB, Mesquita ET. Custo da insuficiência cardíaca no Sistema Único de Saúde. Arq Bras Cardiol. 2005;84(5):422-7.

30. Instituto Brasileiro de Geografia e Estatística (IBGE). Índice Nacional de precos ao consumidoramplo especial - IPCA-E, acumulado anual de 2006 a 2012. [Internet]. [cited 2013 Dec 05] http://www.portalbrasil.net/ipca_e.htm 